\title{
Estimation of modernization potential of Russian federal districts
}

\author{
D. Yu. Fraymovich ${ }^{1} \bowtie$, M. A. Gundorova ${ }^{1}$, Z. V. Mischenko ${ }^{1}$, S. I. Totmyanina ${ }^{1}$, A. Zh. Panzabekova ${ }^{2}$ \\ ${ }^{1}$ Vladimir State University n.a. Alexander and Nikolay Stoletovs, Vladimir, Russia; e-mail: fdu78@rambler.ru \\ ${ }^{2}$ Institute of Economics of the Committee of Science of the Ministry of Education and Science of the Republic \\ of Kazakhstan, Almaty, Kazakhstan
}

\begin{abstract}
The article discusses the resource potential of Russian federal districts involved in processes of modernization. The theoretical framework draws from Russian and international studies of economic potential, stability and efficiency in regional development and regional imbalances. Methodologically, the research relies on a series of relative indicators of innovation, which can be used to measure federal districts' modernization potential by applying methods of mathematical statistics. The proposed set of criteria allows us to take into consideration both the current situation and the dynamics of innovation development in Russian regions. The selected indicators characterize the returns from innovation investment in socio-economic systems, the degree of regional differentiation within districts and trends of regional development regarding the efficiency of innovation processes. The proposed approach can be used to measure the efficiency of human capital use. To test the above-described methodology, we decided to focus on the Central Federal District, which has a significant resource potential necessary to meet the demands of intensive modernization. Statistical comparison of the actual and limit values has revealed significant underused resources in this district. These resources can be accessed by stimulating the lagging regions. The described methods and results of this study can be used by research organizations, higher education institutions, regional authorities and policy-makers in the process of preparation, adjustment and monitoring of strategic programs of socio-economic development.
\end{abstract}

\section{Оценка модернизационно-ресурсного потенциала федеральных округов России}

\author{
Д. Ю. Фраймович ${ }^{1} \bowtie$, М. А. Гундорова ${ }^{1}$, 3. В. Мищенко ${ }^{1}$ С. И. Тотьмянина ${ }^{1}$, А. Ж. Панзабекова ${ }^{2}$ \\ ${ }^{1}$ Владимирский государственный университет имени А. Г. и Н. Г. Столетовых, г. Владимир, Россия; \\ e-mail:fdu78@rambler.ru \\ ${ }^{2}$ Институт Экономики Комитета Науки Министерства образования и науки Республики Казахстан, \\ 2. Алмать, Казахстан
}

\section{АННОТАЦИЯ}

В статье рассматривается ресурсный потенциал федеральных округов России, вовлеченных в процессы модернизации. Теоретическая основа статьи построена на российских и международных исследованиях экономического потенциала, региональных дисбалансов, стабильности и эффективности регионального. Методологически исследование опирается на ряд относительных показателей инноваций, которые можно использовать для измерения модернизационного потенциала федеральных округов путем применения методов математической статистики. Предложенный набор критериев позволяет учитывать как текущую ситуацию, так и динамику инновационного развития в российских регионах. Выбранные показатели характеризуют отдачу от инновационных инвестиций в социально-экономические системы, степень региональной дифференциации по районам и тенденции регионального развития в отношении эффективности инновационных процессов. Предложенный подход может быть использован для измерения эффективности использования человеческого капитала. Чтобы проверить вышеописанную методологию, мы решили сосредоточиться на Центральном фе-

\section{КЛЮЧЕВЫЕ СЛОВА}

федеральный округ, ресурсный потенциал, модернизационный потенциал, инновация 
деральном округе, который обладает значительным ресурсным потенциалом, необходимым для удовлетворения потребностей интенсивной модернизации. Статистическое сравнение фактических и предельных значений выявило значительные недоиспользованные ресурсы в этом районе. К этим ресурсам можно получить доступ, стимулируя отстающие области. Описанные методы и результаты данного исследования могут быть использованы исследовательскими организациями, высшими учебными заведениями, региональными органами власти и политиками в процессе подготовки, корректировки и мониторинга стратегических программ социально-экономического развития.

\section{ДЛЯ ЦИТИРОВАНИЯ}

Fraymovich D. Yu., Gundorova M. A. Mischenko Z. V., Totmyanina S. I., Panzabekova A. (2019) Estimation of modernization potential of Russian federal districts. R-economy, 5(4), 176-188. doi: 10.15826/ recon.2019.5.4.018

\section{Introduction}

Processes of resource formation and use in Russian federal districts are the main focus of a number of state programs aimed at stimulating modernization in federal districts and adapted for specific socio-economic, geographical, infrastructural, scientific and technological conditions in these districts. The programs are targeted at maximizing the economic potential of territories, which makes it pertinent to devise and improve methods of estimating this potential. Straightforward estimation is impossible in this case and it is necessary to minimize the statistical parameters characterizing only certain parts of general development trends. It is also important to take into account the long time lag to ensure that the results of monitoring could present an objective picture of regional innovation trends. Furthermore, it is crucial to analyze the information about the existing regional imbalances, their causes and measures taken to deal with them. It should be noted that analysis results can be reliable only if the research uses official statistical data, coherent and consistent methodology and quantified measures.

\section{Theoretical framework}

The development of conceptual approaches to fostering regional innovation, according to E. B. Lenchuk, at its initial stage, requires creation of a full 'inventory valuation' of the region's economic and industrial potential [1, p. 16].

It should be noted that most research papers discussing the methods of evaluating regional innovation capacity identify a specific range of resources which are considered to be strategically important (principal component) [2-4]. For instance, the study of the innovative potential of twelve northern Russian regions is based on 21 indicators available in official statistics [2]. After processing primary indicators by method of principal components, the researchers identified five basic factors whose characteristic values were greater than unity and covered most of the total variance (about 90\%) in the monitoring period between 2012 and 2014. Then, using the hierarchical cluster analysis, the authors identified the groups of regions with different levels of innovation potential and drew these groups' profiles.

The majority of such studies rely on quantitative (precise) calculation methods and representative sets of factors divided into separate blocks and reflecting the degree of resource development. However, this methodology is applied to analyze short intervals, which somewhat limits the judgement about the dynamic component of resource development in particular regions. Nevertheless, this approach is quite relevant and can be useful as a part of expanded methodology for diagnostics of innovation potential in Russian region.

Another modern approach of assessing the efficiency of research and development (R\&D) activity in regions was proposed by a team of scholars from the Financial University (Moscow) [3] the DEA-modeling method (Data Envelopment Analysis), based on building an efficient frontier in the space of 'input' and 'output' variables. The first group of input (i.e. resource-related) components includes the following: the number of $\mathrm{R} \& \mathrm{D}$ organizations; share of innovation-active organizations; number of staff involved in research work; expenses for technological innovations; expenses for research and development. The second group of output (resulting) characteristics includes the following: the number of submitted patent applications and granted patents; scope of shipped innovation products; number of publications in journals indexed in the international abstract research database; developed and used advanced production technologies; share of graduate students and doctoral candidates with defended papers. Regions' performance is determined by degree of their proximity to the specific frontier, adopted as a benchmark (reference point) and built via repeated solution of the linear programming problem. The indisputable methodological advantage of this approach is its focus on using 
advanced methods of data analysis (DEA-modeling and R-project system) as well as further ranking of regions by various individual indicators by taking into account their entropy defined through Shannon's equation.

There is, however, one aspect of this methodology that requires extra clarification - the practical side of the correlation between the results of research and development (R\&D) activity and the region's potential (resources). The researchers have proposed the following formula to calculate efficiency $\exists_{R \& D}$ :

$$
\ni_{S I A}=\frac{R_{i R \& D}}{P_{J R \& D}},
$$

where $R_{i R \& D}$ is the results of research and development; $i=1 \ldots r ; P_{i R \& D}$, the potential, $j=1 \ldots p$. In general, $r \neq p$.

What raises most questions is the interpretation of the results of division: for instance, the number of publications (result) by the share of innovation-active organizations (resource description) looks quite problematic. Moreover, the selection of the optimal scale which the final figure should tend to is quite complicated.

Yet another problem is that the proposed approach does not indicate the time interval of calculations to rank the regions according to their $\mathrm{R} \& \mathrm{D}$ performance.

Nevertheless, we must give credit to the authors of the method for their use of modern analytical systems and tools in processing of significant data arrays and for obtaining valuable results suitable for practical implementation in regional development programs.

Not denying the importance of assessing efficient resource development in regions, it would be reasonable to add that, to ensure the prosperity of the whole state, it is more important to analyze explicit and latent reserves for innovative growth (in terms of federal districts) on the level of federal districts. A key organizational and managerial aspect is to identify the specific characteristics of the innovation policy design and implementation in federal districts by taking into consideration the structure of their innovation potential and role in the national economy [5, p. 60]. Therefore, a closer look is needed at the main trends in regional performance, which renders crucial the questions of the patterns of growth, stability, dynamics, and predictability in development of socio-economic systems. The methodological framework for studying these questions is con- stantly updated [6-9]. For example, American scholars E. Hill, H. Viall, and H. Volman define stability as the area's ability to recover successfully from economic shocks, which either push it off the path of growth or at least have such potential [6]. A similar definition is offered by K. Foster, who identifies stability as a region's ability to anticipate, prepare for, respond to, and recover from disorder [7]. According to L. Geely and H. Harass [8], who analyzed the dynamics of change in well-being of South-East Asia population, the rate of long-term economic growth is of fundamental importance for society's living standards; it is an irreplaceable mechanism for getting people out of poverty.

According to researchers from the Russian Presidential Academy of National Economy and Public Administration (Moscow), a conceptual framework for the theory of regional stability as a field of Russian regional economics should comply with the contemporary Western (European) standards. This will allow Russian economists to develop guidelines and recommendations for regions to be able to maintain their viability in situations of crisis by mitigating external threats and their impact on socio-economic growth [9, p. 180].

Modernization processes and their effectiveness in federal districts is mostly determined by the depth of innovative transformations on the regional level. Of course, territorial transformations occur unevenly, which significantly affects the degree of resource development and realization of the overall economic potential on the national level. Recently, much scholarly attention has been focused on the issues of regional differentiation [10-14]. P. Krugman introduced his core-periphery model in 1991 and thus made a significant contribution to systematization of our knowledge about the conditions and patterns of resource concentration within a limited area (region) [10]. As most current research shows, however, provision of a higher level of living standards is often impeded by the severe economic imbalance within a state or region. Therefore, experts studying socio-economic systems find it crucial to define and justify the reasons behind significant interregional imbalances in specific indicators; to identify the optimal variance boundaries (based on the cases of success); and to describe the prospects of leveling these differences through targeted state support. As for significant regional differences, some regions tend to accumulate the advantages at the expense of others, which can exacerbate the crisis 
and leads to the disruption in homogeneity of the socio-economic space. Unequal regional development means slower economic growth, depletion of human capital, underperformance of regions in terms of technological development, declining public trust in the government, weaker economic and social relations [11, p. 68].

According to V. N. Leksin, apart from depopulation in the vast areas of Russia, the crisis of the settlement system has led to the degradation and lumpenization of a large part of the country's labor force, reduction in the country's economic potential [12, p. 4]. Further increase in the interregional differentiation will require the federal centre to take new political decisions to level the differences [13, p. 148].

There is no doubt that such unbalanced economic structure means higher risk and requires revision of the currently implemented public policies of innovation support as well as a significant reduction in the influence of Moscow agglomeration to the benefit of other regions. This is due to the fact that concentration of financial and infrastructural resources in one region in potentially adverse market conditions may lead to deterioration of the entire socio-economic system, whose economic processes mostly depend on a particular area. Such trend should be addressed through various state programs aimed at redistribution of funds in favor of depressed, struggling areas. The goals of such programs should include the renewal of fixed assets, development of knowledge-intensive enterprises and establishment of modern infrastructure in the production sector, in research and education.

R. Bakhtizin, however, is quite pessimistic about this trend, pointing out that 'financial equalization' through money transfers from the federal budget to heterogeneous regional economies is nothing but a 'mothballing' strategy as it does not create sufficient incentives for economic growth. Subsidies have no practical effect on investment processes in regions and do not ensure sufficient stimulation for efforts of regional authorities to develop business and attract investors on the basis of public-private partnership. Therefore, financial equalization does not necessarily lead to economic leveling [14, p. 88].

In order to get an understanding of how Russian federal districts make use of their resource potential to modernize, we need to analyze this situation in different dimensions and identify the prospects of regional development by taking into account the state of the current socio-economic and innovation environment.

\section{Research methods}

The lack of complete data on the dynamics and scope of current transformations in Russian federal districts leads us to using combinatorial values based on official Rosstat data. It should be noted that significant differences between constituent areas in a federal district (according to the key modernization parameters) imply that there are organizational and economic opportunities to reduce the detected differentiation by involving the resources which often remain unused in certain areas [15, p. 43].

Our diagnostics of the modernization potential of federal districts was conducted by using special computer software, whose applicability is confirmed by the state registration certificate [16]. For our assessment, we chose a series of seven relative indicators on the basis of the available Rosstat data on R\&D development of Russian regions. These indicators show the degree of development for certain types of resources and final level of use for economic modernization potential in federal districts - from 2000 to 2017.

1. Indicator of efficiency for innovative activities $I_{\ni}$ of enterprises in a specific federal district in the last analyzed period (2017) is calculated by formula (1):

$$
I_{\ni}=\frac{1}{n} \sum_{i=1}^{n} \frac{V_{i}}{C_{i}},
$$

where $V_{i}$ is the scope of innovative products, works, services in the $i^{\text {th }}$ region of the federal district; $C_{i}$, the costs of technological innovations in the $i^{\text {th }}$ region of the federal district; and $n$, the number of regions in this federal district.

It should be noted that to calculate the payoff from innovation in the relevant period, we need to use the data on the expenditures in the previous year - given the chain reaction (delay in a certain time lag) of production facilities for funding the technological innovation.

Performance indicator of a research organization operated in $I_{P}$ district, achieved in the last analyzed period (2017), is calculated by formula (2):

$$
I_{P}=\frac{1}{n} \sum_{i=1}^{n} \frac{T_{i}}{O_{i}},
$$

where $T_{i}$ is the number of advanced production technologies in the $i^{\text {th }}$ region of the federal district; $O_{i}$ the number of $\mathrm{R} \& \mathrm{D}$ organizations in the 
$i^{\text {th }}$ region of the federal district; $n$ is the number of regions in this federal district.

This criterion indicates the level of activity for scientific organizations in a certain area.

3. Variation factor $k_{\ni}$ for efficiency of innovation in regions of a certain federal district, in the last analyzed period (2017), looks the following way (3):

$$
k_{\ni}=\frac{\sigma_{I_{\ni}}}{I_{\ni}}
$$

where $\sigma_{I_{3}}$ ia the mean root square deviation of performance indicators for innovation in regions of this federal district.

This indicator shows the degree of territorial segregation by payoff from innovation and it should be aimed at the minimum possible value.

4. Variation factor for operating performance of $\mathrm{R} \& \mathrm{D}$ organizations $k_{P}$ in regions of a certain federal district, for the last analyzed period (2017), is calculated by formula (4):

$$
k_{P}=\frac{\sigma_{I p}}{I_{P}},
$$

where $\sigma_{I_{p}}$ is the mean root square deviation of operating performance indicators for $\mathrm{R} \& \mathrm{D}$ organizations in regions of this federal district; $k_{P}$ provides information on the degree of regional imbalance (by performance of $\mathrm{R} \& \mathrm{D}$ organizations) and it should have a downward trend.

5. For a federal district, the indicator of stable development (by efficient innovative activities) is found on the basis of (5):

$$
s_{\ni}=\left\{\begin{array}{cc}
s_{\ni}, & p \leq \alpha \\
0, & p>\alpha
\end{array},\right.
$$

where $k_{\ni}$ is the coefficient of time factor $t$ in linear regression equation $I_{\ni}=s_{\ni} \cdot t+b_{\ni} ; b_{\ni}$, the permanent offset; $p$, the significance of influence caused by time factor $t$ on indicator $I_{\ni}$ in the regression model defined during variance analysis; , the critical value of significance level $p$.

Indicator $\left(s_{\ni}\right)$ reflects the tendencies and predictability in the performance indicators of innovation, while characterizing the tangent of the formed trend with respect to the time axis. It should be noted that it is also important to test the significance of regression equation $(p)$. The stability factor is accepted if $p \leq 0.05$

6. The stability factor for the development of a federal district (by efficient functioning of R\&D organizations $s_{P}$ ) is found on the basis of (6):

$$
s_{P}=\left\{\begin{array}{cc}
s_{P}, & p \leq \alpha \\
0, & p>\alpha
\end{array},\right.
$$

where $s_{P}$ is the coefficient of time factor $t$ in linear regression equation $I_{P}=s_{P} \cdot t+b_{P} ; b_{P}$, the permanent offset; $p$, the significance of influence caused by time factor $t$ on indicator $I_{P}$ in the regression model defined during variance analysis; $\alpha$, the critical value of significance level $p$.

Indicator $\left(s_{P}\right)$ shows a stable change in the performance indicators of R\&D organizations $\left(I_{P}\right)$ in the given federal district. In the way similar to previous criterion, it takes a specific value, if $p \leq 0.05$. Otherwise, the stability factor is assumed to equal zero.

7. Efficiency indicator on use of human capital $I_{C}$ in the federal district, for the last analyzed period (2017), is calculated by formula (7):

$$
I_{C}=\frac{1}{n} \sum_{i=1}^{n} \frac{V_{i}}{P_{i}},
$$

where $P_{i}$ is the labor force in the $i^{\text {th }}$ region of this federal district.

The proposed indicator $\left(I_{C}\right)$ describes the relative scope of innovation product, made by one able-bodied person in the territory of a certain federal district, within a certain time interval. In fact, you can say that it shows the performance of high-tech labor in monetary terms.

An opportunity for successful modernization of the federal district's economy appears, if the indicators are greater than or equal to the limit values, which can be calculated by using the statistical data on economically successful (in terms of innovation) Russian regions or international practice.

\section{Results}

For further calculations, we are going to use the data on the three most industrially developed federal districts (Central Federal District, Volga Federal District, and Ural Federal District), which together have for a long time accounted for about $65 \%$ of the country's GDP. Furthemore, it would be reasonable to compare the obtained indicators with the corresponding values for the whole of Russia, which can be taken as normative values.

For our calculations we used the official data from the statistical digests "Regions of Russia. Socio-Economic Indicators" published by Rosstat ${ }^{1}$. A fragment of the calculations of the performance

${ }^{1}$ Retrieved from: http://www.gks.ru/wps/wcm/connect/ rosstat main/ rosstat/ru/statistics/publications/catalog/ 
Table 1

Indicators of innovation in Russian regions for 2001-2017

\begin{tabular}{|c|c|c|c|c|c|c|c|c|c|c|c|c|c|c|c|c|c|}
\hline $\begin{array}{r}\text { Terri } \\
\text { (region }\end{array}$ & 2001 & 2002 & 003 & 2004 & 2005 & 2006 & 2007 & 2008 & 2009 & 2010 & 2011 & 2012 & 2013 & 2014 & 2015 & 2016 & 2017 \\
\hline $\mathrm{RF}$ & & & & & & & & & & & & & & & & & \\
\hline & 11 & 3.89 & 54 & .59 & 3.53 & 86 & 4.60 & 6.10 & .86 & 3.00 & 4.62 & .40 & 3.82 & .58 & 3.95 & .08 & .12 \\
\hline & & & & & & & 18.21 & & & & & & 13.04 & 20.86 & 7.14 & & ונ. \\
\hline & 8.06 & 22.56 & 65 & 22.76 & 18.46 & & 13.78 & 12.22 & 13.81 & 10.67 & & & 274 & & & .64 & \\
\hline & .53 & 3.52 & 3.66 & 3.78 & 3.11 & 0.46 & 5.27 & 2.75 & 2.38 & 1.55 & 6.52 & .99 & 6.45 & 1.83 & 4.57 & 2.13 & 5.05 \\
\hline & 2 & 4.3 & 5.26 & 7.01 & 10.88 & 13 & 7.64 & 4.56 & .20 & 2.87 & 4.89 & .80 & 2.05 & 3.27 & 7.40 & 2.74 & 4.20 \\
\hline & & & & & & & & & .04 & 0.61 & & & 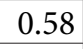 & & נית & 0.92 & 0.01 \\
\hline & & 8.00 & & & & & 6.15 & & .37 & 5.29 & & & 2.35 & 88 & .10 & 1.20 & 1.80 \\
\hline & 3.59 & 3.25 & 99 & 5.97 & 1.14 & 1.20 & 2.31 & 7.27 & 4.93 & 3.83 & 3.99 & 7.51 & 3.14 & 4.96 & 4.52 & 5.36 & 12.73 \\
\hline & & & & & & & 02 & 17 & 63 & 31 & 94 & .39 & .09 & 13 & 3.32 & 24.16 & 13.58 \\
\hline & 59 & 0.98 & 7.04 & 58.95 & 9.59 & .70 & 9.25 & 9.42 & 16.98 & 1.23 & 1.40 & 1.28 & 4.62 & 6.40 & 5.67 & 6.81 & 3.99 \\
\hline & 22 & & & & & 7.49 & 11.32 & & 7.57 & 7.93 & 8.64 & & 56 & & .73 & 2.66 & .03 \\
\hline & .44 & 22.71 & & & & & & & 1.60 & 7.34 & & & 2.99 & & .08 & .14 & 0.93 \\
\hline & .55 & & & & & & 2.68 & & 2.44 & 3.77 & 2.16 & & 0.95 & 1.01 & .77 & 2.97 & 3.08 \\
\hline & 15.01 & 15.22 & 6.87 & 1.68 & 0.71 & 2.17 & 3.67 & 3.60 & 4.17 & 2.10 & 1.79 & 1.60 & 3.64 & 7.29 & 3.18 & 1.52 & 3.29 \\
\hline & & & & & & & 69 & & 2.71 & 2.10 & & & 0.92 & & .06 & 2.44 & 1.90 \\
\hline & & & & & 4.03 & & 4.31 & 16.55 & 14.89 & 10.08 & 11.66 & & 4.69 & 73 & .15 & 4.94 & .98 \\
\hline & & & & & & & 0.91 & & 0.67 & 1.31 & 7.38 & 11.40 & 4.16 & 4.40 & 6.31 & 5.74 & 4.65 \\
\hline & & & & 4.60 & & 6.65 & 2.60 & 3.91 & 2.56 & 3.69 & 2.22 & & 1.51 & 2.04 & 1.13 & 4.13 & 8.08 \\
\hline Ioscow city & 0.33 & 0.87 & 0.38 & 1.93 & 2.20 & 3.38 & 2.38 & 3.74 & 1.87 & 2.48 & 6.93 & 2.88 & 3.88 & 4.10 & 4.80 & 4.79 & 0.88 \\
\hline
\end{tabular}

indicators for innovation in the regions of the Central Federal District and for Russia in general, based on formula (1), is shown in Table 1.

As for the question of potential anomalies in the development of the area (in particular of the Central Federal District), it should be noted that our study focuses exclusively on relative indicators, which ensure objective assessment of the results of innovation processes. If we look at the absolute statistical indicators (amount of innovative production, turnover of small businesses, etc.), we will see that the city of Moscow occupies the dominant position, its results exceeding those of other regions ten and hundred times. If we calculate specific values (turnover per capita, per enterprise, etc.), however, they may present us with a radically different picture. As Table 1 illustrates, in 2017, the value of indicator $I_{\ni}$ in Moscow (0.88) exceeds only that of Ivanovo region (0.61) and therefore it is by no means extraordinary. Therefore, our methodology enables us to make calculations for geographically and economically large regions. Table 2 illustrates the calculations of indicators " 2 " and " 4 " (by using formulae (2) and (4)), which characterize the performance of R\&D organizations $I_{P}$ and variability
$k_{P}$ of these indicators in the regions of the Volga Federal District in 2017.

For the graphical analysis of the distribution of the values of $I_{\ni}$ and $I_{\mathrm{p}}$ and their changes in the reporting periods (2000-2017), we used Statistica 10.1 software to build the range chart (see Figure 1 and 2).

Table 2

Performance of R\&D organizations in the Volga Federal District, in 2017

\begin{tabular}{|l|r|r|r|}
\hline \multicolumn{1}{|c|}{ Region } & \multicolumn{1}{c|}{$\boldsymbol{I}_{\boldsymbol{P}_{\boldsymbol{i}}}$} & \multicolumn{1}{c|}{$\boldsymbol{\sigma}_{\boldsymbol{I}_{\boldsymbol{p}}}$} & \multicolumn{1}{c|}{$\boldsymbol{k}_{\boldsymbol{P}}$} \\
\hline Volga Federal District & 0.33 & 0.24 & 0.73 \\
\hline Republic of Bashkortostan & 0.11 & - & - \\
\hline Mari El Republic & 0.38 & - & - \\
\hline Republic of Mordovia & 0.59 & - & - \\
\hline Republic of Tatarstan & 0.50 & - & - \\
\hline Udmurtia & 0.64 & - & - \\
\hline Chuvash Republic & 0.11 & - & - \\
\hline Perm Region & 0.51 & - & - \\
\hline Kirov Region & 0.04 & - & - \\
\hline Nizhny Novgorod Region & 0.33 & - & - \\
\hline Orenburg Region & 0.03 & - & - \\
\hline Penza Region & 0.07 & - & - \\
\hline Samara Region & 0.39 & - & - \\
\hline Saratov Region & 0.18 & - & - \\
\hline Ulyanovsk Region & 0.75 & - & - \\
\hline
\end{tabular}


As seen from the first chart (Figure 1), the degree of variation in efficiency indicators for innovation development in the regions of the Central Federal District for the given period (2001-2017) shows a clear downward trend.

On the one hand, in the light of the national task of reducing the interregional differentiation, the current situation in this district looks quite optimistic. On the other hand, we still cannot say that the median values of the analyzed indicators are improving and, therefore, there is no evidence of a pronounced positive trend, which would show any return on the government spending on technological innovation.

A change in the median of the efficiency indicator (innovation activity in the regions of the Central Federal District) may be considered insignificant - compared to random fluctuations

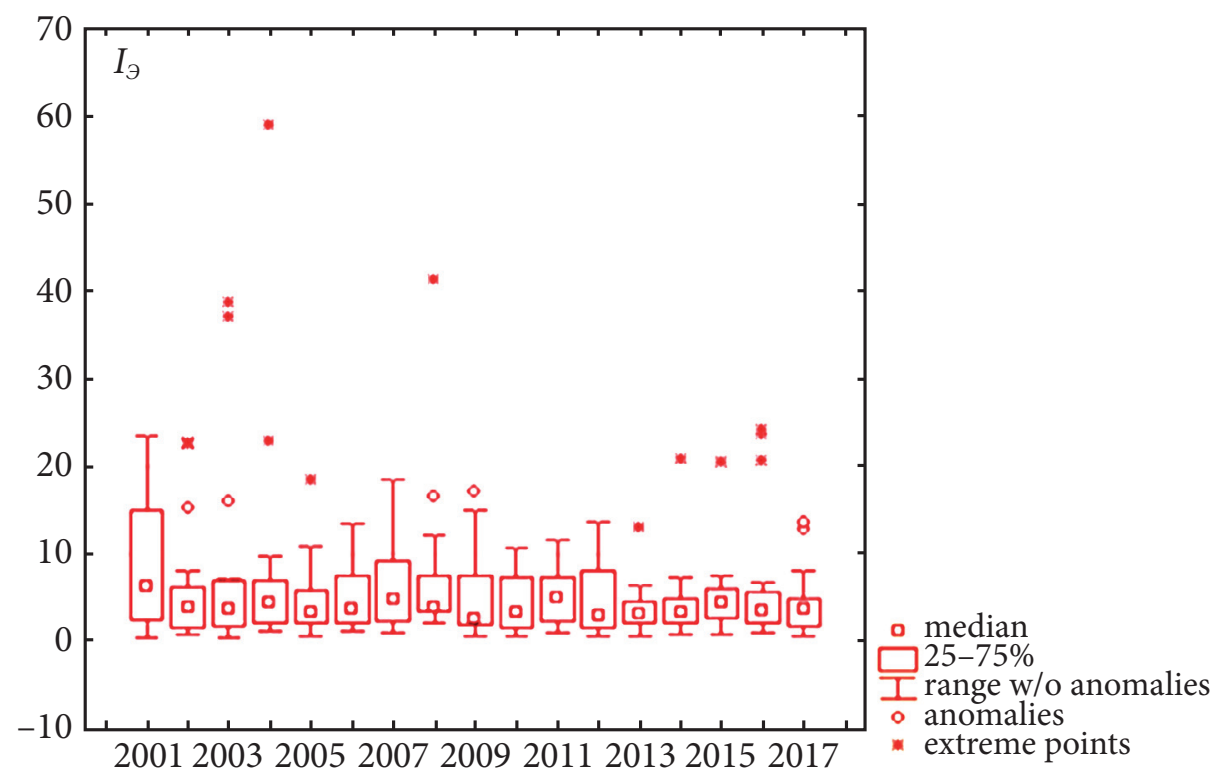

Figure 1. Range chart of performance indicator values for innovation in regions

of the Central Federal District, in 2001-2017

Note: "Median" signifies the value splitting the analyzed sample of 18 regions in two groups (9 regions demonstrate values below the median, and 9 regions, above the median); "25\%-75\%" is the rectangle corresponding to $25 \%$ and $75 \%$ quartiles; "Range without anomalies" stands for the range of indicator values with no account for anomalies in observations; "anomalies" are the points corresponding to anomalies; "extreme points" are the points corresponding to extreme values in the sample

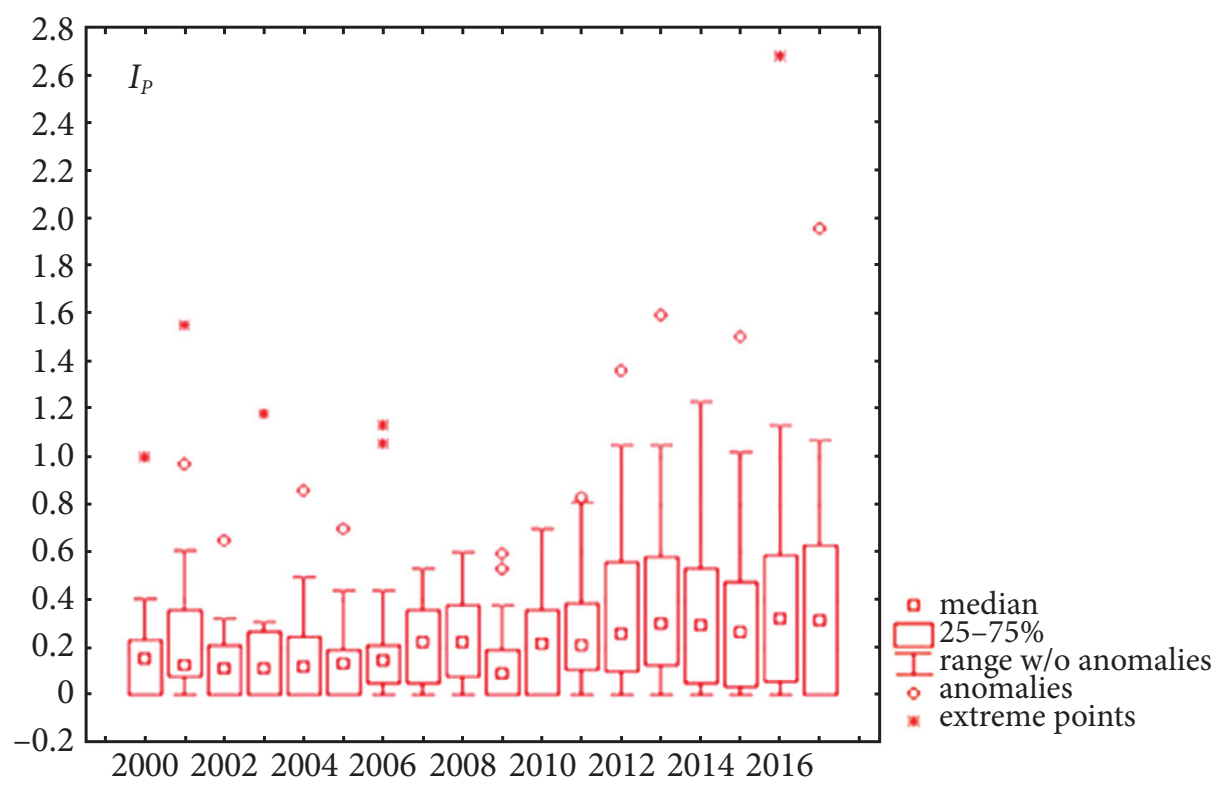

Figure 2. Range chart of performance indicators for R\&D organizations in regions of the Central Federal District, 2000-2017 
of $I_{\ni}$ values in individual regions. It allows us to conclude that the average efficiency of innovation in the district remains virtually unchanged. However, this indicator shows isolated positive anomalies, which means that there are leading regions and that other regions also have some potential for modernization due to the available reserves for potential growth in returns on the spending on technological innovation.

The analysis of performance indicators for R\&D organizations in 2000-2017 (see Fig. 2) showed a minor change in $I_{P}$ median in the regions of the Central Federal District compared to random factors.

In the given period, the range of values shows substantial heterogeneity (including the interquartile range), which increased considerably since 2012. It may be interpreted as a sign of significant disparities between the regions in terms of their R\&D organizations' performance.

To assess the stability of modernization processes by using formulae (5) and (6), we conducted a retrospective analysis of the values of innovation performance and efficiency of R\&D organizations (in the given federal districts and Russia in general, in 2000-2017). The results of these calculations are shown in Table 3.

To calculate the stability of innovation efficiency indicators and performance indicators of R\&D organizations (based on the data in Table 3), we conducted a paired regression analysis and estimated the statistical significance of the obtained factors. Figure 3 illustrates the results of the analysis for the Central Federal District.
As follows from the results of the analysis of innovation efficiency indicator $I_{\ni}$ in the Central Federal District (depending on the reporting period), the effect of the time factor, compared to random factors, is insignificant since Fisher's statistical significance level is $86.8 \%$, which substantially exceeds the critical level of $5 \%$. Therefore, the stability value of innovation efficiency indicators $s_{\ni}$ (for this district, in 2001-2017, for (5) criterion) is taken as equal to zero.

Table 3

Indicators of innovation efficiency $I_{\ni}$ and performance indicators of R\&D organizations $I_{P}$ in Russian federal districts, 2000-2017

\begin{tabular}{|l|r|c|c|c|c|c|c|c|}
\hline \multirow{2}{*}{ Year } & \multicolumn{2}{|c|}{ Central } & \multicolumn{2}{c|}{ Volga } & \multicolumn{2}{c|}{ Ural } & \multicolumn{2}{c|}{ Russia } \\
\cline { 2 - 9 } & $\boldsymbol{I}_{\boldsymbol{\ni}}$ & $\boldsymbol{I}_{\boldsymbol{P}}$ & $\boldsymbol{I}_{\boldsymbol{\ni}}$ & $\boldsymbol{I}_{\boldsymbol{P}}$ & $\boldsymbol{I}_{\boldsymbol{\ni}}$ & $\boldsymbol{I}_{\boldsymbol{P}}$ & $\boldsymbol{I}_{\boldsymbol{I}}$ & $\boldsymbol{I}_{\boldsymbol{P}}$ \\
\hline 2000 & - & 0.16 & - & 0.26 & - & 0.36 & - & 0.17 \\
\hline 2001 & 2.11 & 0.13 & 4.92 & 0.28 & 2.12 & 0.42 & 2.95 & 0.16 \\
\hline 2002 & 3.89 & 0.14 & 1.95 & 0.24 & 7.05 & 0.66 & 3.02 & 0.19 \\
\hline 2003 & 2.54 & 0.24 & 3.02 & 0.24 & 5.05 & 0.58 & 3.36 & 0.22 \\
\hline 2004 & 3.59 & 0.14 & 4.28 & 0.31 & 4.17 & 0.31 & 3.58 & 0.18 \\
\hline 2005 & 3.53 & 0.14 & 6.74 & 0.27 & 2.47 & 0.35 & 3.74 & 0.18 \\
\hline 2006 & 4.86 & 0.18 & 9.48 & 0.30 & 3.66 & 0.44 & 5.43 & 0.20 \\
\hline 2007 & 4.60 & 0.18 & 6.79 & 0.31 & 2.64 & 0.38 & 4.54 & 0.20 \\
\hline 2008 & 6.10 & 0.22 & 6.68 & 0.33 & 2.39 & 0.25 & 4.71 & 0.21 \\
\hline 2009 & 3.86 & 0.20 & 4.42 & 0.30 & 1.08 & 0.39 & 3.04 & 0.22 \\
\hline 2010 & 3.00 & 0.27 & 6.72 & 0.27 & 1.34 & 0.48 & 3.12 & 0.25 \\
\hline 2011 & 4.62 & 0.30 & 9.86 & 0.29 & 1.95 & 0.59 & 5.26 & 0.31 \\
\hline 2012 & 3.40 & 0.29 & 5.75 & 0.42 & 1.43 & 0.61 & 3.92 & 0.37 \\
\hline 2013 & 3.82 & 0.38 & 4.62 & 0.39 & 1.78 & 0.76 & 3.88 & 0.40 \\
\hline 2014 & 3.58 & 0.33 & 4.14 & 0.46 & 1.29 & 0.76 & 3.22 & 0.39 \\
\hline 2015 & 3.95 & 0.34 & 3.62 & 0.33 & 1.76 & 0.74 & 3.17 & 0.33 \\
\hline 2016 & 4.08 & 0.37 & 4.73 & 0.40 & 3.03 & 0.98 & 3.63 & 0.38 \\
\hline 2017 & 2.12 & 0.33 & 5.58 & 0.34 & 3.30 & 0.96 & 3.24 & 0.36 \\
\hline
\end{tabular}

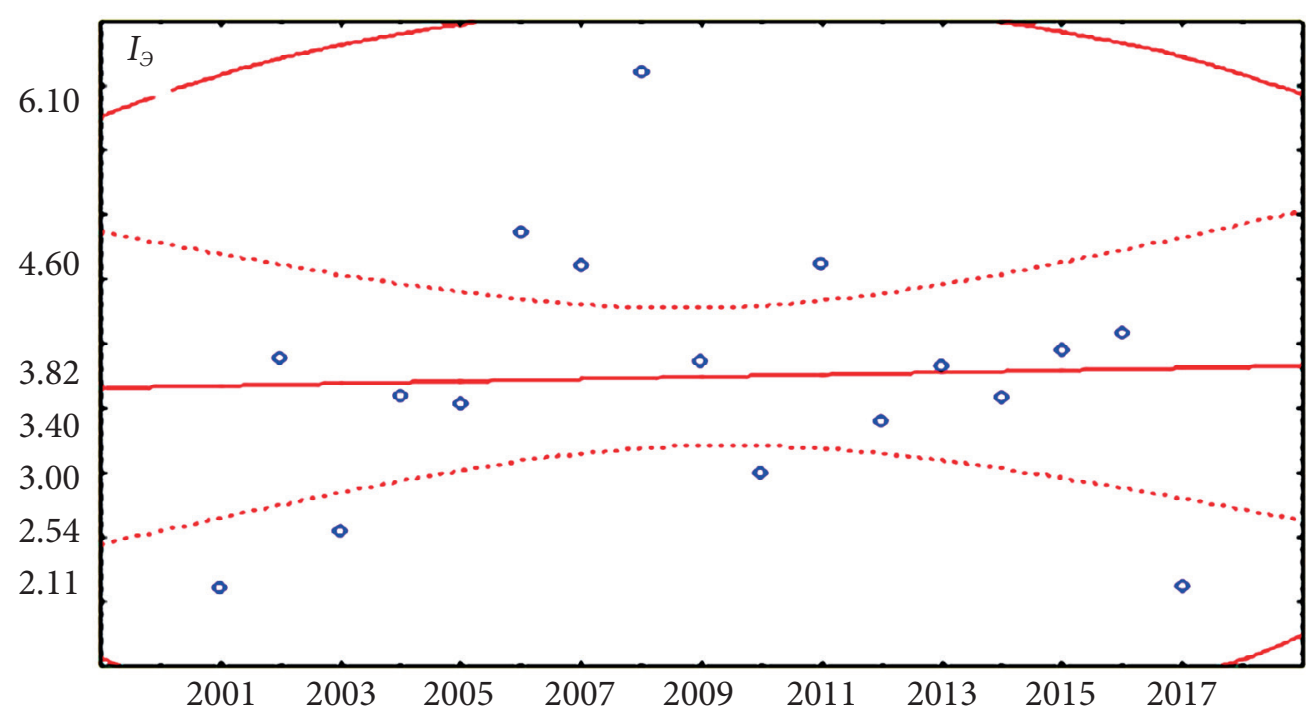

Figure 3. Graph of the linear regression dependence between indicator and time, for the Central Federal District, in 2001-2017 


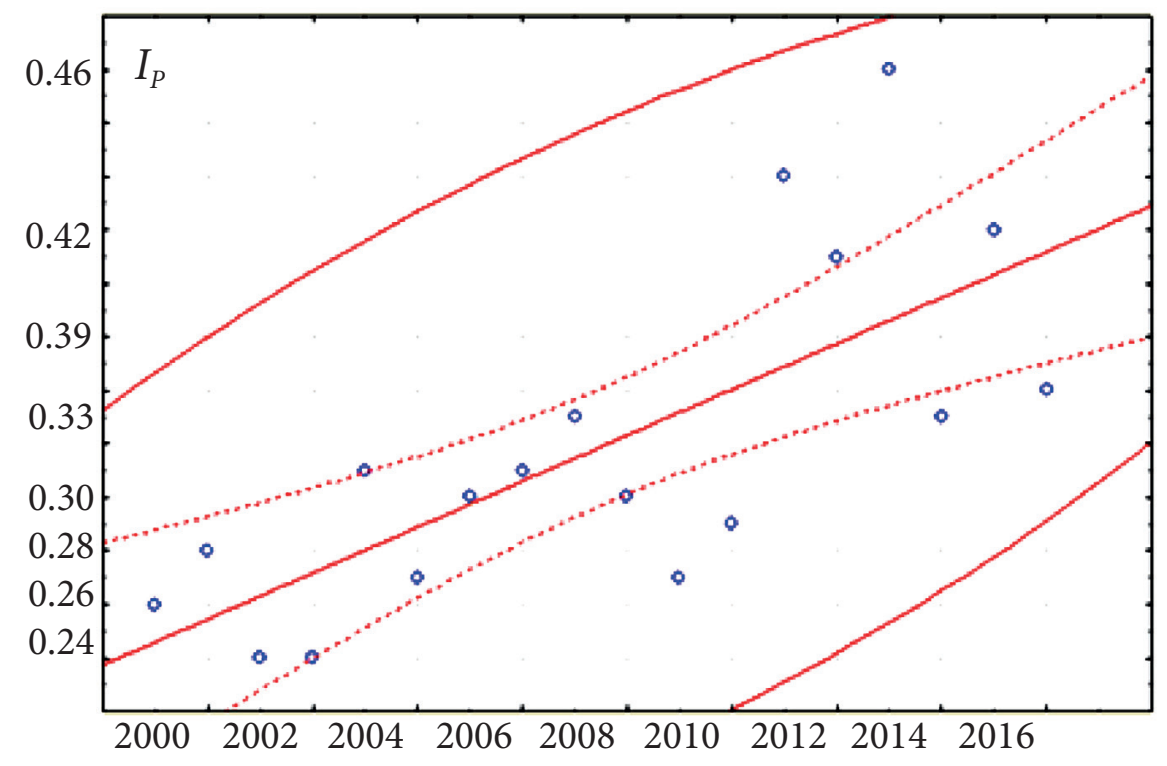

Figure 4. Graph of the linear regression dependence between $I_{P}$ indicator and time (for the Volga Federal District)

The graphical analysis of the dependence between the innovation efficiency indicator and time (in Russia and the Volga Federal District) leads us to a similar conclusion. It is nearly impossible to detect any development in the trend or trend slope (set by the regression equation) against the background of random factors, i.e., confidence limits. It follows from the above that the stability value of innovation efficiency in Russia and the Volga Federal District is $s_{\ni}=0$.

In line with the given criteria, the innovation development is quite pronounced (compared to previous cases) in the Ural Federal District. Location of the observed $I_{\ni}$ values along the confidence limits, the negative tangent of the trend line with respect to the time axis, relatively high modulus of the correlation factor $(r=-0.51)$, and significance level $p=0.035$ lead us, according to condition (5), to estimate the stability value for the Ural Federal District as $s_{\ni}=-0.159$.

The results of our statistical analysis of the stability factors for performance indicators of R\&D organizations $I_{P}$ were obtained for all given territories in the way similar to the previous stage of calculations, based on condition (6). For example, the graph of the linear regression dependence between $I_{P}$ indicator and time (for the Volga Federal District) looks as follows (Figure 4).

The results of the regression analysis for the stability indicator (performance parameters of research organizations in the Volga Federal District), depending on reporting period, show that the effect of the time factor, compared to random factors, is significant: Fisher's statistical significance level is $p=0.5 \%$. In this case, the regression equation looks the following way: $I_{P}=-0.6213+0.0086 t$, where $t$ is the reporting time period. Therefore, for the Volga Federal District, in 2000-2017, the stability indicator is taken as equal to $s_{P}=0.0086$

For the Central Federal District, this indicator is $s_{P}=0.0146$; for Russia, $s_{P}=0.0147$; for the Ural Federal District, $s_{P}=0.0296$.

Our calculation of the seventh indicator, reflecting the efficient use of human capital in the district for 2017 (formula (7)), allows us to conclude that, in the Central Federal District, this potential is not rationally used - compared to average Russian figures as well as the results of the Ural and Volga federal districts. The lag from the reference indicator (for the Volga Federal District) is $40 \%$ (Figure 5 ).

Territories

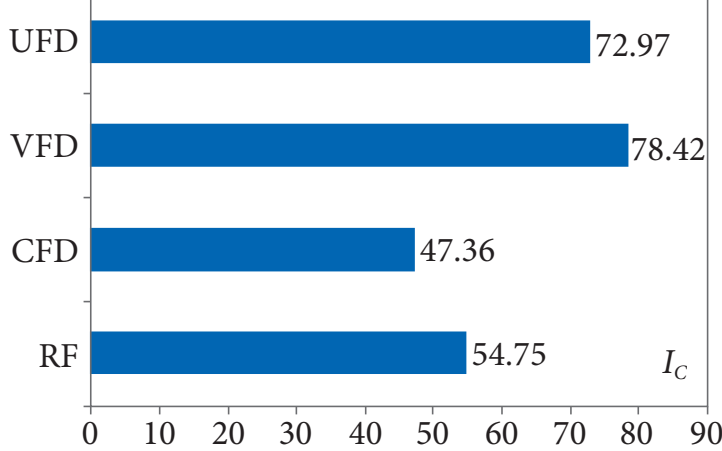

Figure 5. Graphic interpretation of the indicators of efficiency of human capital use

in Russian federal districts $\left(I_{C}\right)$, ths rbs/person 
Table 4 summarizes the results of our calculation of the actual parameters (1)-(7) in the given federal districts and Russia in general.

Table 4

Actual values of (1)-(7) indicators for federal districts and Russia

\begin{tabular}{|c|r|r|r|r|}
\hline Indicators & Central FD & Russia & Volga FD & Ural FD \\
\hline$I_{\ni}$ & 4.340 & 8.818 & 6.156 & 6.520 \\
\hline$I_{P}$ & 0.437 & 0.430 & 0.331 & 1.035 \\
\hline$k_{\ni}$ & 0.860 & 3.368 & 0.510 & 1.645 \\
\hline$k_{P}$ & 1.161 & 1.484 & 0.732 & 1.161 \\
\hline$S_{\ni}$ & 0.000 & 0.000 & 0.000 & -0.159 \\
\hline$S_{P}$ & 0.015 & 0.015 & 0.009 & 0.030 \\
\hline$I_{C}$ & 47.362 & 54.750 & 78.424 & 72.975 \\
\hline
\end{tabular}

However, for accurate comparison of territories within the unified assessment system, these values require some standardization, i.e., being brought to a common comparative base. Thus, we are going to conduct a two-level analysis according to standard and reference criteria.

The indicator values we obtained for Russia can be referred to as standard indicators while the best results for the given federal districts, as reference These limits are taken as $1(100 \%)$. If an increase of the factor is caused by the improvement of the situation in the sphere of innovation (indicators "1"-“"2", "5"-“7"), the specific value for the selected federal district (numerator) is correlated with the standard and reference indicators for other districts (country). The inverse relationship between the changes of the factor and the improved situation (indicators " 3 "- " 4 ") means that we need to change the procedure and correlate the limit values with the actual ones (for the given district). We tested our methodology for diagnostics of regional modernization potential by using the data on the Central Federal District (Table 5).

Table 5

Results of calculations of standardized indicators "1"-“7" for the Central Federal District

\begin{tabular}{|c|c|c|c|c|}
\hline \multirow[t]{2}{*}{$\begin{array}{c}\text { Indica- } \\
\text { tor }\end{array}$} & \multirow{2}{*}{$\begin{array}{c}\text { Normative } \\
\text { indicators } \\
\text { (for the } \\
\text { Central } \\
\text { Federal } \\
\text { District) }\end{array}$} & \multirow[t]{2}{*}{$\begin{array}{c}\text { Reference } \\
\text { indica- } \\
\text { tors }\end{array}$} & \multicolumn{2}{|c|}{$\begin{array}{l}\text { Development of the } \\
\text { district's modernization } \\
\text { potential in comparison } \\
\text { with: }\end{array}$} \\
\hline & & & $\begin{array}{l}\text { Normative } \\
\text { indicators }\end{array}$ & $\begin{array}{l}\text { Reference } \\
\text { indicators }\end{array}$ \\
\hline$I_{\ni}$ & 1 & $1(\mathrm{RF})$ & 0.49 & 0.49 \\
\hline$I_{P}$ & 1 & 1 (UFO) & 1.02 & 0.42 \\
\hline$k_{\ni}$ & 1 & 1 (VFD) & 3.92 & 0.59 \\
\hline$k_{P}$ & 1 & 1 (VFD) & 1.28 & 0.63 \\
\hline$S_{\ni}$ & 1 & $1(-)$ & - & - \\
\hline$S_{P}$ & 1 & 1 (UFO) & 0.99 & 0.49 \\
\hline$I_{C}$ & 1 & 1 (VFD) & 0.87 & 0.65 \\
\hline
\end{tabular}

Since estimation of modernization of potential of a regional economy is conducted by using a set of indicators " 1 "-" 7 ", the general result will be presented as a radar chart. Figure 6 shows the diagram of the summary data from Table 5.

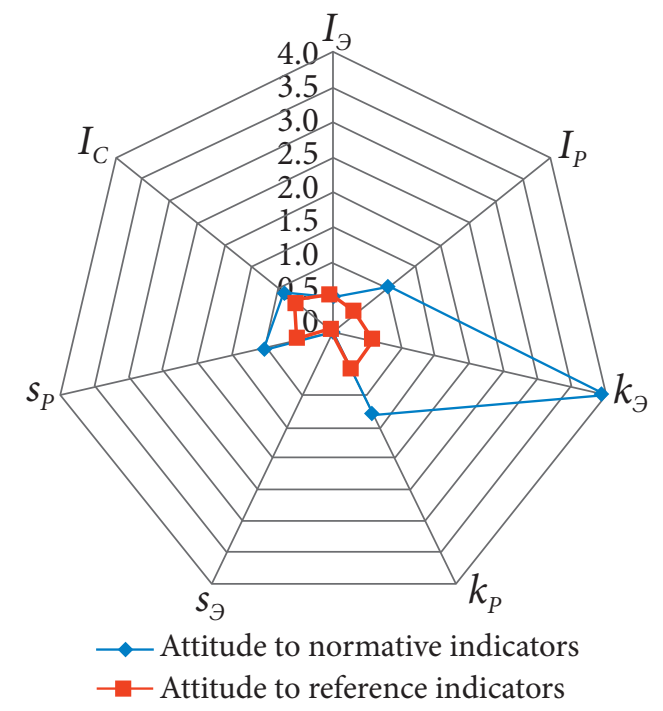

Figure 6. Radar chart for estimating modernization potential of the economy of the Central Federal Districts for indicators (1)-(7)

We compared indicators " 1 "-“7" for the Central Federal District with the standard and reference values, which led us to the following conclusion. The results of this district are unsatisfactory for the majority of parameters. Moreover, this alarming trend can be observed in other, more developed regions of Russia as well as for the overall situation in the country (standard values).

Thus, $I$ indicator for the Central Federal District is twice lower than the standard and reference value for the whole country, while being 30\% below that of the Volga and Ural federal districts. The dynamics of all the given federal districts in terms of innovation efficiency also leaves much to be desired. In this situation, the position of the Central Federal District can be described as "equal among the worst": Russia in general as well as the Central and Volga federal districts demonstrate zero stability in the indicators of return on innovation investment (see Table 4). Within the confidence limit, pronounced stability in the selected indicators with respect to the time axis is characteristic only of the Ural Federal District. However, the annual decrease in efficiency, which can be seen from the negative tangent of trend $\left(s_{\ni}=-0.159\right)$, does not give us grounds for optimism regarding the turnover of innovative products (per one ruble of modernization expenses). 
The results of the Central Federal District, on the contrary, offer some hope, compared to standard values of interregional variability in innovation efficiency $\left(k_{\ni}\right)$ and effectiveness of R\&D organizations $\left(k_{p}\right)$. Moreover, it should be noted that stability $\left(s_{P}\right)$ of $\left(I_{P}\right)$ indicators in 2000-2017 is comparable to the limit values for Russia. These facts mean that the district has some real potential for adoption of new knowledge $\left(I_{\ni}\right)$, efficient functioning of R\&D organizations $\left(I_{P}\right)$, and the full use of human capital $\left(I_{C}\right)$. Furthermore, variation factor $k_{P}$ for the Central Federal District is almost $60 \%$ above the similar reference value for the Volga Federal District, thus indicating significant under-used resources in the district, which can be accessed by stimulating lagging regions. Thus, it seems appropriate to classify the Central Federal District as a territory with considerable modernization potential.

Our analysis on the basis of quantitative approach has enabled us to create an indicator system (for diagnostics of a federal district) and conduct comprehensive monitoring of the district's capabilities. At that, the system of indicators (1-7) allows us to take into consideration the current situation as well as to estimate the dynamic component. Indicators $I_{\ni}, I_{P}$, and $I_{C}$ characterize the return on the unit of resources invested into innovation within a district; $k_{\ni}$ and $k_{p}$, differentiation of regions within a district; $s_{\ni}$ and $s_{P}$, trends of district development in terms of innovation efficiency and performance. Based on that, the proposed indicator system and analytical methods can be applied to conduct diagnostics of the modernization potential of a federal district, relying on the minimum possible amount of statistical data.

In general, although the Central Federal District has a developed infrastructure and considerable research and manufacturing capabilities as well as a favourable geographical location, it fails to use its modernization potential efficiently enough. Meanwhile, there are actual targets for building this potential - in the form of specific innovation results demonstrated by the district, both in the reporting period and in a long period of time. Furthermore, the reference values of indicators $I_{P}$ and $S_{P}$ for the Central Ural District as well as indicators $k_{\ni}, k_{P}$ and, $I_{C}$ for the Volga Federal District indicate that there are opportunities for better use of territorial economic reserves.

\section{Conclusions}

Modernization transformations in Russian federal districts are stimulated through state strategic programs adapted for specific socio-economic, geographical, infrastructural, scientific and technological conditions of territories. Analysis of these conditions cannot consist only of straightforward estimations and rely on a limited number of factors. Calculation results need to reflect innovation trends in federal districts by taking into account a long retrospective time lag. It should be noted that for adequate diagnostics of modernization potential of territories, we need to use official statistical data, coherent and consistent methodology and quantified measures.

The proposed series of relative indicators of innovation can be used to measure federal districts' modernization potential by applying methods of mathematical statistics. Our approach is based on analysis of national data and official statistics characterizing modernization processes in Central, Volga and Ural federal districts in the 18-year period (from 2000 to 2017). The proposed set of criteria allows us to take into consideration both the current situation and the dynamics of innovation development. The selected indicators characterize the returns from innovation investment in socio-economic systems, the degree of regional differentiation within the district and trends of regional development regarding the efficiency of innovation processes. The proposed approach can be used to measure the efficiency of human capital use.

The methodology was tested on the data on the Central Federal District, which was found to hold a considerable potential for modernization in socio-economic systems of its regions. Statistical comparison of the actual and limit values revealed significant underused resources in this district. These resources can be accessed by stimulating the lagging regions. We found significant variability in innovation efficiency within the Central Federal District in comparison with reference values for other districts. The district has also demonstrated some comparatively positive dynamics regarding the efficiency of its $\mathrm{R} \& \mathrm{D}$ organizations in 2000-2017, which means that it is possible to improve the district's overall performance and realize its human potential more fully. The proposed system of indicators and quantitative methods can be applied to conduct diagnostics of federal districts' modernization potential by using the minimum amount of statistical information and to identify the regions that do not fit into the general development trends. 


\section{References}

1. Lenchuk, E. B. (2016). National technological initiative as strategic vector of industrial policy of Russia. Problemy teorii i praktiki upravleniya = Theoretical and Practical Aspects of Management, 2, 8-19. (In Russ.)

2. Gadzhiyev, Yu. A., Styrov, M. M., Kolechkov, D. V., \& Shlyakhtina, N. V. (2016). Analysis of innovation potential of Northern Russian regions. Ekonomicheskie i socialnye peremeny: fakty, tendencii, prognoz = Economic and Social Changes: Facts, Trends, Forecast, 6, 236-254. (In Russ.)

3. Loseva, O. V., Abdikeev, N. M., \& Didenko, A. S. (2018). Ranking and clustering of regions by level of efficiency of scientific and innovative activity. Nauchny 'e trudy ' VE 'O Rossii = Scientific Works of the Free Economic Society of Russia, 3, 146-161. (In Russ.)

4. Kasa, R. (2015). Approximating innovation potential with neurofuzzy robust model. Investigaciones Europeas de Dirección y Economía de la Empresa, 21, 35-46.

5. Kurchenkov, V. V. (2013). Innovative activity of the enterprises in the conditions of the global competition. Innovacii = Innovations, 5, 60-64. (In Russ.)

6. Foster, K. A. (2007). A Case Study Approach to Understanding Regional Resilience. Working Paper, Institute of Urban and Regional Development, University of California, Berkeley, 2007-08. Retrieved from: https://iurd.berkeley.edu/wp/2007-08.pdf

7. Hill, E. W., Wial, H., \& Wolman, H. (2008). Exploring Regional Economic Resilience. Working Paper, Institute of Urban and Regional Development, University of California, Berkeley, 2008-04. Retrieved from: https://www.econstor.eu/bitstream/10419/59420/1/592859940.pdf

8. Gili, L., \& Kharas, H. (2007). An East Asian Renaissance: Ideas for Economic Growth. World Bank Publications, Washington DC. Retrieved from: http://documents.worldbank.org/curated/ en/517971468025502862/pdf/399860REPLACEM1601OFFICALOUSE0ONLY1.pdf

9. Klimanov, V. V., Kazakova, S. M., \& Mikhaylova, A. A. (2018). Regional resilience: theoretical bases of formulation of the question. Ekonomicheskaya politika = Economic policy, 6, 164-187. (In Russ.)

10. Krugman, P. (1991). Increasing Returns and Economic Geography. Journal of Political Economy, 3, 483-499.

11. Gubanova, E. S., \& Kleshch, V. C. (2017). Methodological aspects in analyzing the level of non-uniformity of socioeconomic development of regions]. Ekonomicheskie $i$ socialnye peremeny: fakty, tendencii, prognoz = Economic and Social Changes: Facts, Trends, Forecast, 1, 58-75. (In Russ.)

12. Leksin, V. N. (2012). Crisis of a system of resettlement in the context of cardinal transformation of the territorial organization of the Russian society. Rossijskij ekonomicheskij zhurnal = The Russian economic magazine, 1, 3-44. (In Russ.)

13. Kolomak, E. A. (2013). Uneven spatial development in Russia: explanations of new economic geography. Voprosy Ekonomiki = Economy questions, 2, 132-150. (In Russ.)

14. Bakhtizin, A. R., Bukhvald, E. M., \& Kolchugina, A. V. (2016). Alignment of regions of Russia: illusions of the program and reality of economy. Vestnik Instituta ekonomiki Rossijskoj akademii nauk = Bulletin of Institute of economy of the Russian Academy of Sciences, 1, 76-91. (In Russ.)

15. Donichev, O. A., Mishchenko, Z. V., \& Fraymovich, D. Yu. (2011). The system of economic-mathematical indicators in assessment of modernization capacity of regions of the federal district. Finansovaya analitika: problemy i resheniya = Financial Analytics: Science and Experience, 44, 42-49. (In Russ.)

16. Mishchenko, Z. V., Fraymovich, D. Yu., \& Gundorova, M.A. (2014). Program for calculation and modeling of a system of economic-mathematical indicators of innovative functioning of regions of the Russian Federation. Copyright certificate. 2014619133 Russian Federation, No. 2014616859/69. (In Russ.)

\section{Information about the authors}

Denis Yu. Fraymovich - Professor of Economics, Vladimir State University n.a. Alexander and Nikolay Stoletovs (79 Gorkogo St., Vladimir, 600005, Russia); e-mail: fdu78@rambler.ru

Marina A. Gundorova - Associate Professor of Economics, Vladimir State University n.a. Alexander and Nikolay Stoletovs (79 Gorkogo St., Vladimir, 600005, Russia); e-mail: mg82.82@mail.ru 
Zorislav V. Mischenko - Associate professor of Economics, Vladimir State University n.a. Alexander and Nikolay Stoletovs (79 Gorkogo St., Vladimir, 600005, Russia)

Svetlana I. Totmyanina - Associate professor of Economics, Vladimir State University n.a. Alexander and Nikolay Stoletovs (79 Gorkogo St., Vladimir, 600005, Russia)

Aksanat Zh. Panzabekova - PhD in Economic Sciences, Associate Professor, Deputy Director for Science of the Institute of Economics of the Committee of Science of the Ministry of Education and Science of the Republic of Kazakhstan (29 Kurmangazy, Almaty, 050000, Kazakhstan); e-mail: aksanat@mail.ru

ARTICLE INFO: received August 20, 2019; accepted October 30, 2019

\section{Информация об авторах}

Фраймович Денис Юрьевич - доктор экономических наук, доцент, профессор кафедры экономики и управления инвестициями и инновациями, Владимирский государственный университет имени Александра Григорьевича и Николая Григорьевича Столетовых (600000, Россия, г. Владимир, ул. Горького, 87); e-mail: fdu78@rambler.ru.

Гундорова Марина Александровна - кандидат экономических наук, доцент кафедры экономики и управления инвестициями и инновациями, Владимирский государственный университет имени Александра Григорьевича и Николая Григорьевича Столетовых (600000, Россия, г. Владимир, ул. Горького, 87); e-mail: mg82.82@mail.ru.

Мищенко Зорислав Владимирович - кандидат технических наук, доцент, Владимирский государственный университет имени Александра Григорьевича и Николая Григорьевича Столетовых (600000, Россия, г. Владимир, ул. Горького, 87).

Тотьмянина Светлана Игоревна - кандидат экономических наук, доцент, Владимирский государственный университет имени Александра Григорьевича и Николая Григорьевича Столетовых (600000, Россия, г. Владимир, ул. Горького, 87).

Панзабекова Аксана Жакитжановна - кандидат экономических наук, доцент, заместитель директора по международному сотрудничеству и внедрению, Институт Экономики Комитета Науки Министерства образования и науки Республики Казахстан (050000, Казахстан, Алматы, ул. Курмангазы, 29; e-mail: aksanat@mail.ru.

ИНФОРМАЦИЯ О СТАТЬЕ: дата поступления 20 августа 2019 г.; дата принятия к печати 30 октября 2019 г.

This work is licensed under a Creative Commons Attribution 4.0 International License

Эта работа лицензируется в соответствии с Creative Commons Attribution 4.0

International License 